\title{
Effects of Cultural and Management Practices on Seed Production of 'Plains' Bluestem
}

\section{R. M. AHRING, C. M. TALIAFERRO, AND L. G. MORRILL}

Highlight: Seed production of 'Plains' bluestem (Bothriochloa ischaemum [L.] Keng.) is difficult to assess because of its indeterminate flowering habit and its vegetative canopy which, when excessive, interferes with seed harvests. The variety will produce two seed crops annually. The first matures in July and the second, if managed properly, in October. The effects of three management treatments on the amount of forage associated with each seed crop were highly significant in 2 out of 3 years. The study suggests that a delay of about 21 days in removing the residual forage remaining after the summer seed harvest will favorably influence fall seed yields. Where nitrogen was applied, the decline in vegetation associated with the seed crop was directly related to the previous year's forage cropping practice. Burning residual litter in early March, fertilizing with a 60-45-0 $(N, P, K)$ pound rate of $N$ and $P$ was best for the production of a summer seed crop. The removal of residual forage by mowing and baling about July 29, cultivation, fertilization, and irrigations as needed, favorably influenced fall seed yields. The combined yield of the two crops in 1969 was in excess of $200 \mathrm{lb} /$ acre pure seed.

Bothriochloa ischaemum var. ischaemum belongs to the tribe Andropogoneae and is composed of warm season, perennial, bunchgrasses locally termed "Old World bluestems." Numerous accessions of these grasses were acquired by the Oklahoma Agricultural Experiment Station and investigated by Harlan and Associates $(1958,1961)$ in basic biosys-

The authors are research agronomist, Plant Science Research Division, Agricultural Research Service, U.S. Department of Agriculture; and associate professors of agronomy, Oklahoma State University at Stillwater.

The paper is a contribution of Plant Science Res. Div., Agr. Res. Serv., U. S. Dep. Agr., and Oklahoma Agricultural Experiment Station at Stillwater.

Manuscript received February 16, 1972.

tematic studies of the genus. Attributes of Old World bluestems include aggressiveness, persistence, and good forage yield potential. Generally, they reproduce by facultative apomixis, have an indeterminate flowering habit, and bear chaffy seeds which are difficult to harvest, process, and plant.

'Plains' bluestem (B. ischaemum var. ischaemum) is a recent varietal release developed from the Old World bluestem collection. The forage production of the variety is at its maximum and of greatest value to livestock in Oklahoma during the summer, i.e., July, August, and September. The cultivar spreads aggressively by volunteer seedlings and will produce seed 
stalks continuously from June until frost. Under proper management, two seed crops are harvestable each ycar: the first matures seed in late June and the second in October. Preliminary observations suggested the major problems involved in seed production of the variety:

1. Continuous seed stalk production, indeterminate flowering habit, thus, lack of uniform seed maturity;

2. Lack of knowledge concerning proper fertility and moisture levels for maximum seed stalk production and seed set;

3. Vegetative canopies which, when excessive, interfere with seed harvests; and

4. The presence of seed-feeding insects (Ahring and Howell, 1968).

Although a number of seed production studies on grasses have been conducted, none to our knowledge have involved any Old World bluestems, i.e., 'King Ranch' (B. ischaemum var. songarica [Rupr.] Celarier); 'El Kan' (B. ischaemum var. ischaemum Keng.); 'Caucasian' (B. caucasia C.E. Hubb); or 'Medio, (Dicanthium papillosum [Hochst.] Stapf.) Generally, seed yields of these Old World bluestem varieties have been low and have been a factor limiting widespread use. Since the success of a seed-propagated forage cultivar is highly dependent on the quantity and quality of seed produced, we undertook to assess the seed production potential of 'Plains' bluestem and to determine what cultural and management practices would enhance seed production.

Published reports of research on grass seed production usually deal with species that produce only one seed harvest per year. Information on practices required for species that mature more than one crop per year is totally lacking for many important forage grass species. Mechanical removal or burning of stubble after harvesting seed is a common management practice of most grass seed growers. Fall burning of cool-season grasses: red fescue (Festuca rubra L.) (Musser, 1947; Pumphrey, 1965); 'Kentucky 31' tall fescue (Festuca elatior var. arundinacea) (Spencer et al., 1950); intermediate wheatgrass (Agropyron intermedium [Host] Beauv.) (Canode, 1965); perennial ryegrass (Lolium perenne L.) (Hardison, 1948); and orchardgrass (Dactylis glomerata L.) (Rampton and Warren, 1963) has been shown to benefit seed production and to aid in the control of several diseases (Hardison, 1960). Spring burning or mechanical removal of plant residue on warm-season grasses is o literature was found on comparative seed production practices other than Burton's (1944) work on several southern grasses. Although fertilization of burned areas gave the greatest seed yields, the percentage increase due to fertilization was greater on unburned plots.

The production of seed on most coolseason grasses is related to nitrogen fertilization. Optimum rates range from 30 to $120 \mathrm{lb}$. N/acre, depending on the kind of grass involved, age of stand, and whether production is under irrigated or dryland conditions. Dates of application vary from spring or fall to split spring and fall in different parts of the country. Similarly, warm season grasses grown for seed respond differently to fertilizer rates and dates of application. A split application of 40 to $30 \mathrm{lb} . \mathrm{N}$ in early spring and at boot stage, respectively, on switchgrass (Panicum virgatum L.) (Harlan and Kneebone, 1953) significantly increased seed yields. However, comparisons made on significantly different between $100 \mathrm{lb} . \mathrm{N}$ applied as one application in early spring or split rates of 40-30 and 70-30 pounds. A mid-August application of $50 \mathrm{lb} . \mathrm{N}$ on blue grama (Bouteloua gracilis (H. B. K.) Lag. ex Steud.) under irrigated conditions significantly increased fall seed yields (Kneebone, 1953). The need for fertilization (Smith, 1948) becomes apparent in grasses producing a summer seed crop about the third year under dryland and the second year under irrigated condithe number of panicles per plot were not

tions. Although seed-yield data on little bluestem (Andropogon scoparius Michx.) was not recorded (Murphy, et al., 1947), nitrogen in combination with phosphorus produced the greatest number of seed stalks. Light applications of nitrogen were not sufficient for maximum seed production, and phosphate alone actually decreased seed stalk production. In addition, Murphy, et al. (1947) reported 45 to $48 \mathrm{lb}$. N produced .91 to $4.2 \mathrm{lb}$. of weeping lovegrass (Eragrostis curvula (Schrad.) Nees.) seed per pound of applicd nitrogen.

\section{Methods}

Studies were initiated in 1968 at the Oklahoma State University Agronomy Research Station, El Reno, Okla. The soil at this location is predominantly a Brewer clay loam with a $\mathrm{pH}$ of approximately 7.3. Soil analyses of the test location showed that it contained 190 to 260 pounds available phosphorus, 645 to 915 pounds available potasssium, and less than 10 pounds nitrate-nitrogen per acre. One acre of 'Plains' bluestem was established in rows 39 inches apart in 1964.

The field layout for the first crop in 1968 consisted of plots in three columns across three blocks and assigning fertility treatments once to each column and to each block in a three-by-three latin square design. In the second and all succeeding crops, the design was modified into a split plot design with randomized forage cropping frequencies (clippings) within each fertility treatment as sub-plot treatments. Three nitrogen fertilizer levels $(0,60$, and $180 \mathrm{lb} . /$ acre) were used. Fertilizer was

Table 1. Mean yields (lb pure seed/acre) of 'Plains' bluestem for summer $\left(\mathbf{H}_{1}\right)$ and fall crops $\left(\mathrm{H}_{2}\right)$ at three management levels and nitrogen (lb/acre) treatments over a 3-year period.

\begin{tabular}{|c|c|c|c|c|c|c|c|c|c|}
\hline \multirow{2}{*}{\multicolumn{2}{|c|}{$\begin{array}{l}\text { Year and } \\
\text { management } \\
\text { treatment } \overline{0 N}\end{array}$}} & \multicolumn{2}{|c|}{$\mathrm{H}_{1}$} & \multirow[b]{2}{*}{ Avg. } & \multicolumn{4}{|c|}{$\mathrm{H}_{2}$} & \multirow{2}{*}{$\frac{\mathrm{H}_{\mathrm{T}}}{\text { Total }}$} \\
\hline & & $60 \mathrm{~N}$ & $180 \mathrm{~N}$ & & $0 \mathrm{~N}$ & $60 \mathrm{~N}$ & $180 \mathrm{~N}$ & Avg. & \\
\hline \multicolumn{10}{|c|}{$1968^{3}$} \\
\hline$\Lambda^{2}$ & 15.9 & 26.5 & 18.1 & 20.2 & 104.7 & 106.7 & 106.5 & 195.9 & 126.1 \\
\hline B & - & - & - & - & 8.5 & 16.4 & 16.2 & 13.7 & 13.7 \\
\hline $\mathrm{C}$ & - & - & - & - & 2.0 & 2.0 & 3.1 & 2.3 & 2.3 \\
\hline Mean & 15.9 & 26.5 & 18.1 & 20.2 & 38.4 & 41.7 & 41.3 & 40.6 & 47.4 \\
\hline \multicolumn{10}{|l|}{$1969^{3}$} \\
\hline A & 29.9 & 81.4 & 98.4 & 69.9 & 118.4 & 166.0 & 70.1 & 118.2 & 188.0 \\
\hline B & 55.4 & 111.0 & 97.0 & 87.8 & 123.0 & 238.2 & 133.7 & 164.9 & 252.8 \\
\hline$C$ & 37.9 & 62.6 & 74.8 & 58.4 & 89.3 & 105.8 & 96.9 & 97.3 & 155.7 \\
\hline Mean & 41.1 & 85.0 & 90.1 & 72.0 & 110.2 & 170.0 & 100.2 & 126.8 & 198.8 \\
\hline \multicolumn{10}{|l|}{$1970^{3}$} \\
\hline A & 24.3 & 39.0 & 103.0 & 55.4 & 96.3 & 100.3 & 82.4 & 93.3 & 148.7 \\
\hline B & 64.1 & 66.9 & 66.7 & 65.9 & - & - & - & & 65.9 \\
\hline $\mathrm{C}$ & 45.2 & 124.8 & 62.9 & 77.6 & 86.4 & 106.1 & 95.9 & 96.1 & 173.7 \\
\hline Mean & 44.5 & 76.9 & 77.5 & 66.3 & 91.3 & 103.3 & 89.1 & 94.7 & 129.4 \\
\hline
\end{tabular}

${ }_{2}^{1}$ Mean of three replications/harvest.

${ }_{2}^{2} \mathrm{H}_{1}$ yields in 1968 were harvested before application of treatments $\mathrm{A}, \mathrm{B}$, and $\mathrm{C}$.

${ }^{3} \mathrm{LSD}_{(.05)}$ Main plots (N-level); Sub-plots (Manage.)

Means 1968

\begin{tabular}{crr}
$\mathrm{H}_{1}$ & $\mathrm{H}_{2}$ & \multicolumn{1}{c}{$\mathrm{H}_{\mathrm{T}}$} \\
\hline- & 8.2 & $-\overline{6}$ \\
64.5 & 66.7 & $43.4 ;$
\end{tabular}

\begin{tabular}{ccc}
$\mathrm{H}_{1}$ & $\mathrm{H}_{2}$ & $\mathrm{H}_{\mathrm{T}}$ \\
\hline- & 5.6 & -
\end{tabular}

Means 1969 $\begin{array}{lll}64.5 & 66.7 & 43.4 ; \\ 58.5 & 33.7 & 53.3\end{array}$ $\begin{array}{lll}37.0 & 49.8 & 58.9\end{array}$

$\begin{array}{lll}53.1 & 23.6 & 63.1\end{array}$


applied to the plots twice a year, once in April and immediately after residue removal following the first seed and forage harvest in July. Blanket applications of $45 \mathrm{lb}$. of phosphorus were applied in April of each year. Irrigation was applied as required to supplement rainfall. Generally, plots were cultivated two or three times per crop each year.

Forage and seed were harvested from all treatments in July $\left(\mathrm{H}_{1}\right)$. Forage cropping frequencies designated as management practices $\mathrm{A}, \mathrm{B}$, and $\mathrm{C}$ were used only on the second or fall seed crop each year $\left(\mathrm{H}_{2}\right)$. Management $A$ consisted of mowing and baling the forage after harvesting the first or summer seed crop in July $\left(\mathrm{H}_{1}\right)$ and allowing regrowth to mature a fall crop. Management $B$ consisted of $A$ plus one additional cropping of the regrowth 21 days after $\mathrm{H}_{1}$. Management $\mathrm{C}$ consisted of $\mathrm{A}$ plus two additional forage cropping dates at 21 and 42 days after $\mathrm{H}_{1}$. The residue remaining after harvesting seed and forage yield from the above plots was burned the following March.

The $\mathrm{H}_{1}$ yields (after the initial year) are measures of the management effects as applied the previous year. With this in mind the data collected were evaluated for:

1. The amount and quality of seed produced as affected by nitrogen fertilization and forage cropping frequencies;

2. The effects management practices $\mathrm{A}, \mathrm{B}$, and $\mathrm{C}$ had on the amount of forage associated with each seed crop; and

Table 2. Mean yields (tons/acre) of 'Plains' bluestem associated with each seed harvest at three management levels and nitrogen treatments (lb/acre) over 3 years. 1

\begin{tabular}{|c|c|c|c|c|c|c|c|c|}
\hline \multirow{2}{*}{$\begin{array}{l}\text { Year and } \\
\text { management } \\
\text { treatment }\end{array}$} & \multicolumn{4}{|c|}{$\mathrm{H}_{1}$} & \multicolumn{4}{|c|}{$\mathrm{H}_{2}$} \\
\hline & $0 \mathrm{~N}$ & $60 \mathrm{~N}$ & $180 \mathrm{~N}$ & Avg. & $0 \mathrm{~N}$ & $60 \mathrm{~N}$ & $180 \mathrm{~N}$ & Avg. \\
\hline \multicolumn{9}{|l|}{$1968^{3}$} \\
\hline $\mathrm{A}^{2}$ & 4.03 & 4.05 & 4.30 & 4.13 & 3.89 & 4.42 & 4.93 & 4.41 \\
\hline B & 3.92 & 4.11 & 4.32 & 4.11 & 3.39 & 4.42 & 4.52 & 4.11 \\
\hline $\mathrm{C}$ & 4.10 & 4.21 & 4.42 & 4.24 & 1.32 & 1.58 & 3.30 & 2.06 \\
\hline Mean & 4.10 & 4.12 & 4.34 & 4.16 & 2.86 & 3.47 & 4.25 & 3.52 \\
\hline \multicolumn{9}{|l|}{$1969^{3}$} \\
\hline A & 3.42 & 4.39 & 4.61 & 4.14 & 1.90 & 2.99 & 3.12 & 2.67 \\
\hline B & 2.49 & 3.64 & 3.35 & 3.16 & 0.69 & 1.63 & 2.41 & 1.57 \\
\hline $\mathrm{C}$ & 1.99 & 2.43 & 2.60 & 2.34 & 0.23 & 0.59 & 0.96 & 0.59 \\
\hline Mean & 2.63 & 3.49 & 3.52 & 3.21 & 0.94 & 1.74 & 2.16 & 1.61 \\
\hline \multicolumn{9}{|l|}{$1970^{3}$} \\
\hline A & 1.86 & 2.38 & 2.29 & 2.18 & 2.37 & 3.24 & 3.46 & 3.02 \\
\hline B & 1.60 & 2.94 & 2.44 & 2.32 & 0.44 & 0.56 & 1.26 & 0.75 \\
\hline $\mathrm{C}$ & 1.32 & 2.29 & 2.34 & 1.98 & 2.14 & 2.90 & 3.42 & 2.82 \\
\hline Mean & 1.59 & 2.53 & 2.36 & 2.16 & 1.65 & 2.23 & 2.71 & 2.20 \\
\hline
\end{tabular}

${ }_{1}$ Means of three replication/treatment by harvest.

${ }_{2}^{2} \mathrm{H}_{1}$ yields in 1968 were harvested before application of treatments $\mathrm{A}, \mathrm{B}$, and $\mathrm{C}$.

${ }^{3} \mathrm{LSD}_{(.05)}$ Main plots (N-level); Sub-plots (Manage.)

Means 1968,

\begin{tabular}{|c|c|c|c|c|}
\hline $\mathrm{H}_{1}$ & $\mathrm{H}_{2}$ & & $\mathrm{H}_{1}$ & $\mathrm{H}_{2}$ \\
\hline 10 & 0.61 & ; & - & 0.46 \\
\hline 1.05 & 0.58 & ; & 0.69 & 0.33 \\
\hline
\end{tabular}

3. Stand longevity and spring recovery as affected by treatment.

Seed was harvested by hand, air dried, hammer-milled, and scalped with a small seed cleaner. The scalped sced was and percent pure seed determinations were made following the method proposed for chaffy seeded grasses by Harlan and Ahring (1960). Yields are reported in pounds of pure seed and forage in tons of plant dry matter per acre.

\section{Results and Discussion}

Both management practices $\mathrm{B}$ and $\mathrm{C}$ significantly reduced the vegetative canopies associated with the summer and fall seed crops. However, the amount of pure seed produced (Table 1) at the fall seed harvest $\left(\mathrm{H}_{2}\right)$ in 1968 was not directly attributable to the forage cropping frequencies of either management $\mathrm{B}$ or $\mathrm{C}$. The seed crops of all management treatments were harvested on the same day in 1968. Seed harvested from the plots of management $\mathrm{B}$ and $\mathrm{C}$ were immature, had a low percent pure-seed content, and thus had low yields. The continuous seed stalk production requires close observation of the pattern of head and field maturity to judge the optimum time for seed harvest. In the remaining two years, plots were harvested by management practice according to stage of maturity (i.e., when $50 \%$ or more of the seed heads, at several locations in the plot, could be stripped easily by pulling the head gently between the fingers). weighed, recorded by plot and treatment,

$0.35 \quad 0.50$

Seed yield differences were highly significant in the fall crop of 1969. Management practice B at all levels of nitrogen produced the greatest amount of pure seed. The quantity of seed produced under $\mathrm{C}$ was not significantly different from $\mathrm{A}$ at any levels of nitrogen used. Management $B$ appeared to reduce the vegetative cover at the harvest of the fall $\left(\mathrm{H}_{2}\right)$ seed crop and resulted in more erect, uniform seed stalk production. The advantage of $B$ over $C$ was due to the lack of sufficient plant recovery under $\mathrm{C}$ with fewer seed stalks and obviously weakened plants. The forage cropping practice of management $\mathrm{B}$ removed the excess forage that interfered with the fall $\left(\mathrm{H}_{2}\right)$ seed harvests of management $\mathrm{A}$, without a loss in seed yields.

The analysis of variance of dry matter produced (forage yield) in conjunction with the summer seed harvests $\left(\mathrm{H}_{1}\right)$ in 1969 showed significant response to management levels (Table 2). Management practices $\mathrm{B}$ and $\mathrm{C}$ significantly reduced thc forage yield associated with seed production the following year. Where nitrogen was applied, the decline in dry matter produced at $\mathrm{H}_{1}$ compared to the control, management A, was directly related to the previous year's forage cropping practice. Summer $\left(\mathrm{H}_{1}\right)$ yields were consistent within years for management A over the 3-year study.

Nitrogen applications did not significantly increase yields at $\mathrm{H}_{1}$ in 2 of the 3 years. Plant dry matter associated with the $\mathrm{H}_{1}$ sccd harvest of each of the 3 years reflects the effects of management practices $\mathrm{B}$ and $\mathrm{C}$ on vigor. Dry matter production on control or non-fertilized (N) plots progressively declined each year. Reduced yields were the result of lowering fertility levels in the soil and, in the case of managements $\mathrm{B}$ and $\mathrm{C}$, the combined effects of increased numbers of harvests and reduced soil fertility.

Additional nitrogen improved forage yields at $\mathrm{H}_{2} \mathrm{~B}$ and $\mathrm{H}_{2} \mathrm{C}$. Table 2 presents the plant dry matter associated with cach seed harvest but excludes the yield of the additional cropping dates of management practices $\mathrm{B}$ and $\mathrm{C}$. The combined harvests of management $B$, excluding $\mathrm{H}_{1}$, averaged over fertility rates of the initial year of study, were considerably greater, 5.63 as compared to 4.41 tons for management A. The amount of plant dry matter produced by management $B$ was reduced at $\mathrm{H}_{1}$ in 1969. This effect was masked in 1970 at $\mathrm{H}_{1}$ because supplemental irrigations were limited during a major part of 
Table 3. Mean dry plant matter (tons/acre) over all harvests by management treatments and nitrogen levels (lb/acre).

\begin{tabular}{ccccc}
\hline \hline $\begin{array}{c}\text { Year and } \\
\text { management } \\
\text { treatment }\end{array}$ & \multicolumn{4}{c}{ Nitrogen Levels } \\
\cline { 2 - 5 } 1968 & 0 & 60 & 180 & Mean \\
A & 7.92 & 8.47 & 9.23 & 8.54 \\
B & 8.67 & 10.09 & 10.56 & 9.77 \\
C & 7.23 & 7.79 & 9.85 & 8.29 \\
Mean & 7.94 & 8.78 & 9.88 & 8.86 \\
1969 & & & & \\
A & 5.34 & 7.38 & 7.73 & 6.82 \\
B & 3.48 & 5.82 & 6.26 & 5.18 \\
C & 2.76 & 4.13 & 4.73 & 3.87 \\
Mean & 3.86 & 5.77 & 6.24 & 5.29 \\
1970 & & & & \\
A & 4.23 & 5.62 & 5.75 & 5.21 \\
B & 3.62 & 5.30 & 6.14 & 5.02 \\
C & 3.46 & 5.19 & 5.76 & 4.80 \\
Mean & 3.77 & 5.37 & 5.89 & 5.01 \\
\hline 1 LSD(05) Main plots (N-level); Sub-plots (Manage.) & \\
Means 1969 - 2.07 Tons & $;$ & 1.07 & \\
Means 1970 - 1.02 Tons & ; 1.07 Tons
\end{tabular}

the growing season (May and June). Significant differences in the amount of dry matter produced in 1970 existed among the three nitrogen levels.

Forage yields produced by management practices $\mathrm{A}$ and $\mathrm{B}$ were significantly higher than $\mathrm{C}$ at the $\mathrm{H}_{1}$ and $\mathrm{H}_{2}$ seed harvest dates in 1969. In 1970, a delay in removing $\mathrm{H}_{1}$ forage in preparation for the fall seed crop was such that the one additional cropping of the forage regrowth of management $B$ was comparable to the second cropping date of the previous year of $\mathrm{H}_{2} \mathrm{C}$. Due to the slow recovery of the $C$ plots after $H_{1}$, additional forage croppings were not taken in that year. The recovery in 1970 of management $\mathrm{C}$ as depicted by the $\mathrm{H}_{2}$ dry matter production was surprising. The species evidently can be heavily abused for 2 years and then rapidly regain its vigor the 3 rd year if managed normally, i.e., management $\mathrm{A}$.

The response to nitrogen fertilization was significant at the last harvest $\left(\mathrm{H}_{2}\right)$ throughout the 3 years of study. The tonnage of dry matter produced each year was generally greater with application rates of $180 \mathrm{lb}$. N/acre, but this was not significantly different from the $60 \mathrm{lb}$. rate. As one moves to a higher fertility level, regardless of management, a higher combined yield was obtained, (Table 3 ). Also, as the management practice was changed from $A$ to $B$ to $C$, there was a reduction in quantity of dry matter produced. The more frequently cropped management $\mathrm{C}$ produced less dry matter than did management A or B at all levels of nitrogen fertilization. Regrowth fol- lowing the cropping practices of management $B$ and $C$ was more rapid with nitrogen applications. Thus residual effects of the different management practices as reflected in tons of dry matter per acre from uniform harvests $\left(\mathrm{H}_{1}\right)$ indicated that nitrogen level and cropping management practices influence yield or amount of vegetative cover present.

The significant responses to nitrogen (main effects) and management practices A, B, and C (sub-plot effects) indicated: 1. The quantity of vegetative material associated with seed production was altered by cropping management in both summer $\left(\mathrm{H}_{1}\right)$ and fall seed $\left(\mathrm{H}_{2}\right)$ crops; 2. Nitrogen applications of approximately $60 \mathrm{lb}$. N/crop/acre were essential for production of maximum yields; and 3 . The normal procedure, management $\mathrm{A}$, or removing the residual forage immediately following the summer seed harvest, was not the best practice.

The study suggests that a delay of about 21 days in removing the forage after the summer $\left(\mathrm{H}_{1}\right)$ seed harvest will probably influence seed yields favorably in the fall. A small but favorable reduction in forage present in the summer harvest the following year, as shown by management practice $B$, is sufficient to promote and increase harvestable seed. However, reduction in vegetative canopies associated with both seed crops can be attained by narrow row spacing. Although data are not presented, a 12- to 24-inch row spacing may be better than 39 -inch rows for seed production of this species under irrigated conditions.

\section{Literature Cited}

Ahring, R. M., and D. E. Howell. 1968. A suggested method of collecting insects associated with forage grass seed production. J. Econ. Entomol. 61:975-981.

Burton, G. W. 1944. Seed production of several southern grasses influenced by burning and fertilization. Agron. J. 36:523-529.

Canode, C. L. 1965. Influence of cultural treatments on seed production of intermediate wheatgrass. Agropyron intermedium (Host.) Beauv. Agron. J. 57:207-210.

Hardison, J. R. 1948. Field control of blind seed disease of perennial ryegrass in Oregon. Phytopath. 38:403-419.

Hardison, J. R. 1960. Technological advances in grass and legume seed production and testing: IV. Disease control in forage seed production. Adv. in Agron. 12:96-106, Acad. Press Inc., New York, N. Y.

Harlan, J. R., and R. M. Ahring. 1960. A suggested method for determining purity of certain chaffy seeded grasses. Agron. J. 52:223-226.

Harlan, J. R., R. P. Celarier, W. L. Richardson, M. H. Brooks, and M. K. Mehra. 1958. Studies on Old World bluestems II. Okla. Agr. Exp. Sta. Tech. Bull. No. T-72.

Harlan, J. R., J. M. J. deWet, W. L. Richardson, and H. R. Chheda. 1961. Studies on Old World bluestems III. Okla. Agr. Exp. Sta. Tech. Bull. No. T-92.

Harlan, J. R., and W. R. Kneebone. 1953. The effect of various methods and rates of nitrogen on seed yields of switchgrass. Agron. J. 35:442-453.

Kneebone, W. R. 1953. Blue grama seed production studies. J. Range Manage. 10:17-21.

Murphy, H. F., H. W. Staten, and W. C. Elder. 1947. The effects of fertilizer on grass seed production. Okla. Agr. Exp. Sta. Bull. No. 319. p 85-90.

Musser, H. B. 1947. The effect of burning and various fertilizer treatments on seed production of red fescue (Festuca rubra L.). Agron. J. 39:335-340.

Pumphrey, F. V. 1965. Fertilizing bluegrass and fine fescue for seed production in northeastern Oregon. Oregon State Univ. Agr. Exp. Sta. Bull. No. 601.

Pumphrey, F. V. 1965. Residue management in Kentucky bluegrass, Poa pratensis L., and red fescue, Festuca rubra. L., seed fields. Agron. J. 57:559-561.

Rampton, H. H., and R. Warren. 1963. Orchardgrass seed production in Oregon. Oregon State Univ. Ext. Bull. No. 811.

Smith, J. E., Jr. 1948. Grass seed production under cultivation in the southern great plains. Cattleman 35(5):26-27.

Spencer, T. J. 1950. Seed production of 'Kentucky 31' fescue and orchardgrass as influenced by rate of planting, nitrogen fertilization, and management. Kentucky Agr. Exp. Sta. Bull. No. 554. 